\title{
11
}

\section{Gendered Tradeoffs}

\author{
Jennifer L. Hook and Meiying Li
}

The literature linking family policy to women's labor market outcomes is a rapidly expanding field, spanning many disciplines and analytic approaches. Several recent reviews provide a solid overview of the field and we refer readers to them (Ferragina, 2019; Hegewisch \& Gornick, 2011; Olivetti \& Petrongolo, 2017; Rubery \& Figueiredo, 2018; Steiber \& Haas, 2012). This chapter has an explicit focus on two central questions: (1) Do generous family policies perpetuate gender inequality? That is, do family policies have unintended consequences or promote women's inclusion into the labor force at the expense of gender equality in labor market outcomes, such as in working hours, occupational integration, or wages? and, (2) do generous family policies promote gender equality for certain groups of women at the expense of other groups of women? We also consider evidence regarding a weaker form of this question - do certain groups of women benefit more from family policies than others? In answering this question, we focus on how policies differentially affect women by social class as measured by educational attainment.

We begin by briefly reviewing the types of evidence brought to bear on these questions. We then turn to the primary questions that animate this review, discussing the literature on gender inequality-promoting effects of family policy and heterogeneity in effects of family policy by social class. We review the uneasy consensus that has emerged around how two of the most

J. L. Hook $(\varangle) \cdot$ M. Li

University of Southern California, Los Angeles, CA, USA

e-mail: hook@usc.edu 
studied family policies—childcare services and parental leave-affect women's employment outcomes in general and differentially by social class. Our review is heavily weighted toward questions that have emerged in the comparative study of women's employment over the last 15 years. For an excellent review of foundational research in the 1990s we refer readers to van der Lippe and van Dijk (2002).

\section{How Do We Know?}

Researchers are generally interested in how variation in family policy is associated with women's labor force participation, employment, work hours, or wages. The recent literature linking family policy to women's labor market outcomes generally draws on individual-level data from anywhere from two to dozens of countries and seeks to explain variation across contexts (for pioneering works in the approach see Gornick, Meyers, \& Ross, 1998; Rosenfeld, Van Buren, \& Kalleberg, 1998). They tend to use cross-sectional data, although recent work exploits variation over time (Blau \& Kahn, 2013; Christiansen, 2016; Cipollone, Patacchini, \& Vallanti, 2014; Nieuwenhuis, 2014; Nieuwenhuis, Need, \& Van der Kolk, 2017; Thévenon, 2009, 2016).

Two primary methodological approaches are used. In the first, researchers compare exemplars of welfare state regimes and assess whether differences across countries are congruent with expectations generated from a comparison of family policy contexts. Work in this vein often draws on EspingAndersen's $(1990,1999)$ "three worlds" typology and his later conceptualization of de-familialization or feminist critiques thereof. Although typologies differ, as detailed in Chapter 6 by Zagel and Lohmann in this volume, the central focus is how the state supports (or does not support) the reconciliation of work and care. A leading conceptualization focuses on four strategies of welfare state support (Misra, Budig, \& Moller, 2007) or familialization (Saraceno \& Keck, 2008). Countries are grouped into categories: (1) the primary caregiver strategy or supported familialism, wherein the state subsidizes women's care work; (2) the primary earner strategy or familialism by default, wherein the state encourages women's employment but provides little support for care; (3) the choice strategy or optional familialism, wherein state policy supports women's choice to work or care; and (4) the earner-career strategy or de-familialist, wherein policy supports the combination of work and care for women as well as men. 
In the second approach, researchers combine individual-level data with contextual-level family policy data in multilevel models. Most studies use hierarchical models with individuals nested within countries. Although these models have been used extensively in the literature, they are criticized in several ways: they are sensitive to the selection and number of countries included, which are typically less than thirty and often much less; data tend to be cross-sectional, thus causal claims are questionable; and many key findings in the literature are based on data from the 1990s, which are now dated (Brady, Blome, \& Kmec, 2020; Steiber \& Haas, 2012).

This second approach requires quantifying indicators of specific policies (e.g., weeks of paid parental leave) or closely linked outcomes of specific policies (e.g., enrollment rates in publicly funded child care programs). There is substantial controversy, however, over how these indicators should be used. One option is to measure family policy as a singular index representing a "broad phenomenon" (Mandel \& Semyonov, 2005, p. 955). For example, Mandel and Shalev (2009) argue that family policies should be treated as an integrated bundle, writing that "while it appears that individual components of the family policy package may contribute to women's attainments, they also have shared effects that cannot be detached from one another, either theoretically or empirically" (p. 1879). Other scholars argue, however, that family policies should be delineated by whether they provide time to care or services to replace care (Kamerman \& Kahn, 1994), that is whether policies are "work-reducing" or "work-facilitating" (Jacobs \& Gerson, 2004). Pettit and Hook (2009) draw on this literature to argue that family policy "conflates a variety of specific policies that may have countervailing effects on women's employment and other economic outcomes" (p. 11). Between the two poles of conceptualizing family policy as an inseparable package versus as individual policies, lies an approach that groups family policies by the type of effect they are likely to have on families. For example, Korpi, Ferrarini, and Englund (2013) create indices to measure three dimensions of family policy: policies that support gendered family arrangements (i.e., encourage women to provide care at home), dual-earner arrangements (i.e., encourage women to work), and dual-carer arrangements (i.e., encourage men to care at home). This last approach most closely resembles the regime or typology approach.

An emerging third main approach is a hybrid, wherein the effects of singular policies are tested for policy or institutional "complementarities" (Thévenon, 2016). Arguing that the impact of family policy on women's employment is likely to be context-dependent, Thévenon examines complementarities between policy pairs (paired interaction terms), institutions (sum of the direct effects of all policies), as well as the effects of policies 
within regimes (policies interacted with regime dummies). He concludes that "female labour force participation reacts differently to different policy measures, depending on the institutional environment in which they play out" (p. 494).

Given the difficulty of establishing causality in macro-level studies, microlevel policy evaluation adds a considerable amount to the evidence base. Studies tend to exploit spatial and temporal variation in implementation of family policy reforms with one country. A review of the methodological issues is beyond scope of this chapter; we refer readers to an excellent discussion in Müller and Wrohlich (2018). Some of the evidence about social class differences in policy effects reviewed below is drawn from this literature. Although superior for establishing causality, these studies are country-specific, raising the question of whether the intervention effects would "travel" to other contexts. Conflicting findings from single country studies and evidence from macro-level analyses (e.g., Thévenon, 2016) suggest researchers use caution extrapolating findings to other countries.

\section{Unintended Consequences, Welfare State Paradoxes, and Gendered Tradeoffs}

\section{Do Generous Family Policies Perpetuate Gender Inequality?}

Mandel and Semyonov $(2005,2006)$ argue that although family policies bring women into the labor market, they create a paradox wherein they have adverse consequences for women's occupational integration and earnings. Family policies incorporate lower-skilled women who would otherwise not be in labor market into employment, which increases the gender gap in wages and occupational sex segregation among those in the labor market, including those who would be in the labor market irrespective of family policies. Specifically, they argue that generous family policy packages lower women's accumulated work experience, promote discrimination against women, and concentrate women in female-typed jobs in the public sector. They test this idea with cross-sectional data from the 1990s for 20 countries housed in the Luxembourg Income Study (LIS) database. They create a singular "welfare state index" composed of parental leave, childcare, and public sector employment. They find that generosity on the index predicts a larger gender pay gap 
(Mandel \& Semyonov, 2005) and women's lower representation in managerial positions (Mandel \& Semyonov, 2006) although their models suggest that the findings are largely driven by parental leave.

Rather than seeing gender inegalitarian consequences of all family policy, Pettit and Hook (2009) argue that each policy should be considered along two dimensions - whether it promotes labor market inclusion or exclusion and whether it discourages or promotes equality among those in the labor force. They examine exemplars of each combination: childcare (inclusion and equality), part-time work (inclusion and inequality), unionization (exclusion and equality), and parental leave (exclusion and inequality). This specification differs from Mandel and Semyonov $(2005,2006)$ in that policies that promote inclusion do not necessarily engender inequality; the key is how women are incorporated. Pettit and Hook (2009) posit that childcare includes women in the labor market and puts them on more equal footing with men, whereas lengthy parental leaves remove women from the workplace for several years, put them on less equal footing with men, and encourage employer discrimination. Thus, the effects of leave and childcare on women's labor market outcomes are not expected to reflect "broad phenomenon," but are potentially countervailing. They explore this idea using up to 63 crosssectional surveys, spanning the years 1969 to 2000, from 21 countries housed in the LIS database. They find support for the proposition that family policies can support both inclusion and equality, finding evidence that childcare supports both employment and occupational attainment, particularly among higher educated women.

Brady et al. (2020) methodologically critique these analyses and provide two analyses refuting the conclusions described above. They analyze LIS data both cross-sectionally (21 countries in the mid-2000s) as well as with a country panel using fixed effects models (12 countries, two time periods, mid-1980s/1990s and mid-2000s). Contrary to the existing literature they not only find no evidence of tradeoffs between labor market outcomes, but that "work-family policies are not associated with labor market outcomes for women or mothers. The vast majority of coefficients for work-family policies fail to reject the null hypothesis of no effects" (Brady et al., 2020, p. 142). They do not explicitly consider, however, differences by class or contextual effects, which are discussed below.

\section{Uneasy Consensus on Policy Effects}

The above discussion reveals that the literature is rife with differing conceptualizations of policy, approaches to analyses, and not surprisingly, empirical 
findings. That said, an uneasy consensus has emerged around publicly funded childcare and to a lesser extent, parental leave.

Childcare provision is associated with higher levels of employment (Christiansen, 2016; Erhel \& Guergoat-Larivière, 2013; Jaumotte, 2003; Thévenon, 2016), particularly among mothers and mothers with young children (Boeckmann, Misra, \& Budig, 2015; Nieuwenhuis, Need, \& Van Der Kolk, 2012; Pettit \& Hook, 2005, 2009; Steiber \& Haas, 2009; Uunk, Kalmijn, \& Muffels, 2005), including positive effects on mothers' working hours (Andringa, Nieuwenhuis, \& Van Gerven, 2015; Boeckmann et al., 2015), preferences for longer working hours (Pollmann-Schult, 2016), and lower motherhood wage penalties (Misra, Budig, \& Boeckmann, 2011). Childcare has also been associated with women's increased representation in professional occupations (Pettit \& Hook, 2009). We describe the consensus as uneasy, however, as there is debate as to whether the employment-promoting effects of childcare provision are causal (Steiber \& Haas, 2012), particularly when effects are assessed with enrollment data (for more on data challenges, see Chapter 24 by Sirén, Doctrinal, Van Lancker and Nieuwenhuis in this volume). Findings from Norway suggest that additional childcare places crowd out informal arrangements and benefit mothers who are already employed (Havnes \& Mogstad, 2011). Positive effects of policy expansion, however, are found in other contexts such as Germany (Bauernschuster \& Schlotter, 2015). Reviewing the literature on family policy, Olivetti and Petrongolo (2017) conclude that evidence supports, "overall positive effects of subsidized child care on female employment" but "no obvious consensus emerges from the literature that has studied the labor market impact of parental leave rights and benefits" (p. 227).

We argue that although the debate about parental leave is more contentious, an uneasy consensus does exist. Parental leave is generally considered employment supportive, especially if it is well paid (Boeckmann et al., 2015). There is evidence, however, that parental leave that is "too long" is associated with lower rates of employment among mothers. That is, there is a curvilinear inverted U-shape for mothers with young children (Pettit \& Hook, 2005). How long is too long? Researchers generally find that leaves over two years depress rather than facilitate employment (Nieuwenhuis et al., 2017; Thévenon \& Solaz, 2013), although some estimates approach three years (Christiansen, 2016; Pettit \& Hook, 2009). Nieuwenhuis and colleagues (2017) conclude that "while short periods of leave can be useful, or even necessary, to maintain women's attachment to the labour market after becoming a mother, very long interruptions of employment indeed seem to be a 'mechanism of exclusion'” (p. 13). Some studies fail to find evidence that 
leave can be too long (Keck \& Saraceno, 2013). Long leave, however, has also been linked to negative consequences in other labor market outcomes, including larger motherhood wage penalties (Misra et al., 2011), particularly for highly educated women (Pettit \& Hook, 2009). Childcare and paid leave of modest duration are also supportive of single mothers' employment (Maldonado \& Nieuwenhuis, 2015; Van Lancker, 2018).

Evidence from single country studies supports the above findings. Extensions of leave delay return to work (Lalive \& Zweimüller, 2009 in Austria; Ziefle \& Gangl, 2014 in Germany) and long leaves can promote discrimination against mothers (Glass \& Fodor, 2011 in Hungary). Glass and Fodor (2011) contend that state policies that make motherhood salient for employers, in the absence of anti-discrimination enforcement, contribute to discrimination. Evidence from the Swedish context finds that controlling for selection, taking 16 months of leave or more has a negative effect on women's upward occupational mobility upon return to work (Evertsson \& Duvander, 2011). We conclude that there is an uneasy consensus on the effects of family policy in general, but the consensus fractures when we consider differences by social class.

\section{Gender-Class Tradeoffs}

\section{Conceptualizing Social Class}

Social class is a complex concept, encompassing both material and cultural accounts. The vast majority of quantitative analyses take a materialist perspective focusing on class divides in opportunities, such as the pay and quality of jobs, and constraints, such as the cost and quality of care (Crompton, 2006; McRae, 2003). Although sociologists tend to favor conceptualizations of class derived from occupational attainment, the vast majority of studies that speak to "class" utilize level of education attainment (Cooke, 2011; Grönlund \& Magnusson, 2016; Korpi et al., 2013; Nieuwenhuis, 2014; Pettit \& Hook, 2009; Steiber, Berghammer, \& Haas, 2016). This arises from both theoretical and practical considerations. Theoretically, the study of women's employment is informed by micro-economic theories emphasizing the importance of human capital, of which education is a primary indicator. Practically, education circumvents the difficulties inherent in assigning non-employed women their partners' social class (see Sorensen, 1994). Educational attainment also tends to be the most readily available and comparable measure in commonly used data sources. Alternate measures used in the literature include "income 
classes" measured by earnings quintiles (Mandel \& Shalev, 2009), and simplified occupational schemes (e.g., managers and professionals, white-collar, and blue-collar and elementary occupations) (Pavolini \& Van Lancker, 2018).

Little work explicitly tests both constraint and cultural explanations for class gaps in women's employment or family policy use. In a recent contribution, Pavolini and Van Lancker (2018) use cross-sectional data from $27 \mathrm{EU}$ countries to examine class gaps in formal childcare usage. They find greater support for materialist explanations; parents' perceptions of availability and affordability of care better explained the persistent class differential in usage than cultural norms about mothers' employment. The authors, however, did not test whether class-specific norms impacted class differentials in usage. Research finds class gaps in gender egalitarianism across welfare states (Shalev, 2008; Svallfors, 2006).

\section{Do Generous Family Policies Promote Gender Equality for Certain Groups of Women at the Expense of Other Groups of Women, Particularly by Social Class?}

Shalev (2008) argues that women's normative and material interests diverge by class with respect to family policies. He argues that generous family policy limits high achieving women's ability to achieve gender equality in the labor market. In a series of studies, Mandel and colleagues find that "generous family policy" promotes gender equality for women at lower socioeconomic levels, whereas ungenerous policy promotes gender equality for more advantaged women (Mandel \& Shalev, 2009; Mandel, 2011, 2012).

As noted earlier, however, effects depend on the type of family policy and these, too, vary by class. Pettit and Hook (2009) find that publicly supported childcare supports higher educated women's employment and occupational attainment, more so than for other women, with no negative effects on wages. This is consistent with research showing that childcare services are utilized more by high-income families than low-income families (Van Lancker, 2013) and childcare expansion benefits the already employed, crowding out informal care (Havnes \& Mogstad, 2011). Hook and Pettit (2016) argue that replacing informal with formal care is likely to benefit employed women's labor market outcomes because formal care is less likely to break down than informal arrangements, which puts mothers on a more equal footing with their colleagues. When looking instead at high rates of part-time employment and lengthy parental leave, Pettit and Hook's (2009) conclusions are consistent with Mandel and colleagues (ibid.), as these policies dampen the wage premiums for highly educated women. 
Korpi et al. (2013) approach the question of tradeoffs among groups of women by examining policy dimensions. They analyze LIS data from around 2000 for 15 countries and categorize family policy on three dimensions: traditional family (child allowances, part-time daycare services, home care allowances, marriage subsidies), dual-earner (daycare services for 0-2, full-time daycare services for over-threes, earnings-related parental leave), and dual-carer (paid leave, paid leave reserved for fathers). They combine dual-earner and dual-carer indicators because they are highly correlated into an earner-carer dimension. They find that earner-carer policies promote the employment of lower educated women "without resulting in significant diminution in women's access to top wages and positions of power" (Korpi et al., 2013, p. 28). They conclude that publicly provided childcare and "judiciously designed parental leave" benefit mothers without creating disadvantages for tertiary educated mothers, and that earner-carer policies can "promote gender egalitarianism and class equality simultaneously" (p. 30).

\section{No Consensus on Class Differences}

In contrast to the relative consensus on family policy impacts on maternal employment, there are conflicting theoretical mechanisms and empirical findings about how the effects of family policies on women's employment vary by women's social class, primarily measured by educational attainment. On the one hand, some argue that highly educated women tend to be in the labor force regardless of motherhood and policy context; it is women with lower levels of education who are more sensitive to variations in context (Del Boca, Pasqua, \& Pronzato, 2009; Korpi et al., 2013). Essentially, workfacilitating contexts sway only women who experience less monetary and intrinsic rewards to employment (Damaske, 2011; Steiber et al., 2016). This is consistent with the mechanism of selection as hypothesized in the welfare state paradox (Mandel, 2011; Mandel \& Semyonov, 2006).

On the other hand, some researchers argue that lower educated women suffer from such low job quality that reconciliation policies fail to be incentivizing, thus more highly educated women are more responsive to family policy conditions (Cipollone et al., 2014). This is consistent with findings that higher levels of publicly provided childcare promote employment more among highly educated than other women, incentivizing women with the most to gain from employment (Pettit \& Hook, 2009). Similarly, Nieuwenhuis (2014) found that paid leave reduces the motherhood employment gap more so among highly educated women than among the less educated. Evidence from Germany found that a legal claim to subsidized 
childcare and the expansion of childcare had positive effects on women's employment, but the effect was weakest for women with lower levels of educational attainment (Boll \& Lagemann, 2019; Müller \& Wrohlich, 2018).

Finally, other researchers find little evidence of differential effects by educational attainment. Keck and Saraceno (2013) hypothesize that lower educated mothers will be more disadvantaged by very short or very long leaves and by high childcare costs. They find, however, that employment penalties linked to education occur independently from (or before) motherhood and family policies (Keck \& Saraceno, 2013).

One potential explanation for discordant findings is that the importance of educational cleavages varies across policy regimes. Hook and Pettit (2016) develop expectations about how family policy regimes are connected to occupational segregation of mothers from childless women and how this varies by women's educational attainment. They find that where conditions enable mothers to devote substantial time to caregiving, through extended parental leaves, for example, occupational inequalities cluster around motherhood. In countries with meager provision for reconciling work and family, occupational inequalities diverge acutely by educational attainment. Finally, in countries where conditions enable mothers to compete in the paid labor force, by providing childcare services, for example, there is less differentiation by motherhood and by educational attainment.

\section{Recent Possibilities}

The gendered tradeoffs literature is an ongoing debate. Promising directions consider how the impact of family policies on women's employment outcomes varies across contexts. For example, cultural norms may moderate the impact of family policies on women's employment outcomes (Kremer, 2007; Pfau-Effinger, 2005). Evidence generally supports that egalitarian gender norms are positively associated with women's employment (Boeckmann et al., 2015; Uunk, 2015; although see Uunk \& Lersch, 2019), although gender norms do not account for family policy effects on women's employment (Uunk et al., 2005). Egalitarian gender norms, however, may moderate the relationship between policy and women's employment outcomes. Budig, Misra, and Boeckmann (2012) examine how gender culture moderates the relationship between family policy and mothers' earnings. They hypothesize that family policies that narrow the motherhood earnings penalty will have a stronger effect in cultural contexts that 
are supportive of maternal employment. They find support for this argument. They conclude, that "cultural attitudes amplify, and even change the nature of, associations between parental leave, publicly funded childcare, and maternal earnings" (Budig et al., 2012, p. 186).

Another potential source of contextual effects comes from the labor market context. Estévez-Abe $(2006,2009)$ argues that in coordinated market economies (CMEs), characterized by long term employment contracts, strong employment protections, and investments in firm-specific training, women are at greater risk of becoming "labor market outsiders" due to breaks in employment. Family policies that encourage breaks in employment may have greater negative effects in CMEs than in liberal market economies (LMEs). Grönlund and Magnusson (2016) connect this work explicitly to the welfare state paradox debate by examining the gender wage gap by skill level in a three country comparison of two CMEs that differ in family policy (Sweden and Germany) and one LME (the UK). They hypothesize that the gender wage gap will be greatest among high-skilled women in Sweden (a CME with dualearner family policies) and that sex segregation and on-the-job training would explain more of the gender wage gap for this group than for others. They do not find support for this proposition. The unadjusted gender wage gap is lowest in Sweden and high-skilled women do not face a larger gender wage gap than women in the other two countries. Furthermore, gender wage gaps among the high skilled in CMEs are not well explained by the hypothesized mechanisms.

Another avenue for contextual consideration of tradeoffs by social class is income inequality. Hook (2015) argues that it is difficult to derive hypotheses about women's employment decisions in different policy contexts without considering both the overall level of income inequality in a country and a woman's social location within it. She contends that in the absence of the state de-familializing care, "there are two central questions: (1) what are the alternatives to family care? and (2) how do these alternatives vary by a family's social location? Available alternatives will depend, in part, on the level of inequality in each country" (Hook, 2015, p. 17). She develops expectations about differences by social class under different regimes of familialization (Saraceno \& Keck, 2008). She finds that in countries with high-income inequality and low de-familialization or optional familialism, families polarize between dual full-time and male breadwinner families, and do so largely by women's educational attainment. She concludes that while class is an important correlate of work-family arrangements in nearly all contexts, it is of utmost importance in countries with higher income inequality, greater reliance on the market, and optional familialism. These arguments have yet to be examined outside of a regime approach. 


\section{Conclusion}

In sum, there is an uneasy consensus around the relationship between family policy and women's labor market attachment and outcomes, and no consensus around class differences in policy effects. Regarding the former, publicly funded childcare promotes mothers' employment with no discernable negative consequences for gender equality in other labor market outcomes, such as the gender wage gap. There are no observed deleterious effects of childcare on any group of women, but there is an open debate on who benefits more or less from childcare provision or expansion. Parental leave is also a valuable tool for promoting mothers' labor market attachment. Leaves that are "too long," however, can depress women's labor market attachment resulting in inegalitarian consequences for other labor market outcomes, such as sex segregation and the gender wage gap. There is no consensus around how these relationships vary by women's social class, although there is some evidence that long leaves harm highly educated women's labor market outcomes the most (consistent with welfare state paradox or tradeoff arguments).

To move this debate forward we need more research that considers multiple labor market outcomes, which is at the crux of the welfare state paradox or tradeoff arguments. To resolve this debate, studies should engage both employment and other labor market outcomes, including intensity, segregation, and wages. We also need better data on policy and innovative ways to include it in our models (see Chapter 24 by Doctrinal et al. in this volume). Common measures of paid parental leave, for example, obscure nuances in replacement rates, caps on replacement rates, eligibility criteria, and flexibility in use. These aspects of policy design should affect the labor market consequences of these policies as well as heterogeneity within countries in the benefits different groups of women receive (Bártová \& Emery, 2018; Ray, Gornick, \& Schmitt, 2010). Our current conclusions in this area are based on less than ideal policy data.

Two key themes emerge from the current research. First, the effects of family policy on women's labor market outcomes are likely to depend on the context in which they are implemented. Recent research provides guidance on how to move forward exploring these complex interactions (e.g., Thévenon, 2016). Second, the effects of policy change are likely to depend on woman's social location. Given that there is no consensus yet on how there are ample opportunities for researchers to move the field forward. We note two important opportunities here. 
First, we need more expansive thinking about context dependence of family policy effects and in relation to heterogeneity of effects within countries. The sparse literature on context dependence has produced important insights but remains under-developed. Furthermore, the strands of the literature on context dependence and heterogeneity in effects within countries have been largely separate, but could produce considerable insight if aligned.

Second, another key opportunity for future research is to consider other aspects of mothers' social location. Although educational attainment dominates cross-national studies of women's employment, single country studies document differences in maternal employment and family policy uptake by race, ethnicity, and nativity (Kil, Neels, Wood, \& de Valk, 2018; Kil, Wood, \& Neels, 2018; Vidal-Coso, 2019). Given the challenges inherent in incorporating country-specific patterns and meanings of race, ethnicity, and nativity in a cross-national design, most work in this area is in the form of single country studies or in two-country comparisons (e.g., Pettit \& Hook, 2009). Expanding cross-national work in this area is important for understanding heterogeneity in policy effects as well as inequality more broadly.

Acknowledgements We gratefully acknowledge Lynn Prince Cooke, Laure Doctrinal, Sebastian Sirén, and the editors for providing helpful comments. We acknowledge funding from the Alexander von Humboldt Foundation for the first author's Humboldt Research Fellowship for Experienced Researchers. The first author also gratefully acknowledges support from the WZB Berlin Social Sciences Center, where she was a Visiting Researcher (2018-2019) in the research groups Demography and Inequality and Work and Care, as well as her hosts Anette Fasang and Lena Hipp.

\section{References}

Andringa, W., Nieuwenhuis, R., \& Van Gerven, M. (2015). Women's working hours. International Journal of Sociology and Social Policy, 35(9/10), 582-599.

Bártová, A., \& Emery, T. (2018). Measuring policy entitlements at the micro-level: Maternity and parental leave in Europe. Community, Work \& Family, 21(1), 3352.

Bauernschuster, S., \& Schlotter, M. (2015). Public child care and mothers' labor supply-evidence from two quasi-experiments. Journal of Public Economics, 123, $1-16$.

Blau, F. D., \& Kahn, L. M. (2013). Female labor supply: Why is the United States falling behind? American Economic Review, 103(3), 251-256. 
Boeckmann, I., Misra, J., \& Budig, M. J. (2015). Cultural and institutional factors shaping mothers' employment and working hours in postindustrial countries. Social Forces, 93(4), 1301-1333.

Boll, C., \& Lagemann, A. (2019). Public childcare and maternal employmentNew evidence for Germany. Labour, 33(2), 212-239.

Brady, D., Blome, A., \& Kmec, J. A. (2020). Work-family reconciliation policies and women's and mothers' labor market outcomes in rich democracies. SocioEconomic Review, 18(1), 125-161.

Budig, M. J., Misra, J., \& Boeckmann, I. (2012). The motherhood penalty in cross-national perspective: The importance of work-family policies and cultural attitudes. Social Politics, 19(2), 163-193.

Christiansen, L. E. (2016). Individual choice or policies? Drivers of female employment in Europe. International Monetary Fund.

Cipollone, A., Patacchini, E., \& Vallanti, G. (2014). Female labour market participation in Europe: Novel evidence on trends and shaping factors. IZA Journal of European Labor Studies, 3(1), 18.

Cooke, L. P. (2011). Gender-class equality in political economies. London: Routledge. Crompton, R. (2006). Class and family. The Sociological Review, 54(4), 658-677.

Damaske, S. (2011). For the family? How class and gender shape women's work. Oxford: Oxford University Press.

Del Boca, D., Pasqua, S., \& Pronzato, C. (2009). Motherhood and market work decisions in institutional context: A European perspective. Oxford Economic Papers, 61(Suppl. 1), i147-i171.

Erhel, C., \& Guergoat-Larivière, M. (2013). Labor market regimes, family policies, and women's behavior in the EU. Feminist Economics, 19(4), 76-109.

Esping-Andersen, G. (1990). The three worlds of welfare capitalism. Cambridge: Polity Press.

Esping-Andersen, G. (1999). Social foundations of postindustrial economies. Oxford: Oxford University Press.

Estévez-Abe, M. (2006). Gendering the varieties of capitalism: A study of occupational segregation by sex in advanced industrial societies. World Politics, 59(1), $142-175$.

Estévez-Abe, M. (2009). Gender, inequality, and capitalism: The "varieties of capitalism" and women. Social Politics, 16(2), 182-191.

Evertsson, M., \& Duvander, A. Z. (2011). Parental leave-possibility or trap? Does family leave length effect Swedish women's labour market opportunities? European Sociological Review, 27(4), 435-450.

Ferragina, E. (2019). Does family policy influence women's employment? Reviewing the evidence in the field. Political Studies Review, 17(1), 65-80.

Glass, C., \& Fodor, E. (2011). Public maternalism goes to market: Recruitment, hiring, and promotion in postsocialist Hungary. Gender \& Society, 25(1), 5-26.

Gornick, J. C., Meyers, M. K., \& Ross, K. E. (1998). Public policies and the employment of mothers: A cross-national study. Social Science Quarterly, 79: $35-54$. 
Grönlund, A., \& Magnusson, C. (2016). Family-friendly policies and women's wages-is there a trade-off? Skill investments, occupational segregation and the gender pay gap in Germany, Sweden and the UK. European Societies, 18(1), 91-113.

Havnes, T., \& Mogstad, M. (2011). Money for nothing? Universal child care and maternal employment. Journal of Public Economics, 95(11-12), 1455-1465.

Hegewisch, A., \& Gornick, J. C. (2011). The impact of work-family policies on women's employment: A review of research from OECD countries. Community, Work \& Family, 14(2), 119-138.

Hook, J. L. (2015). Incorporating 'class' into work-family arrangements: Insights from and for three worlds. Journal of European Social Policy, 25(1), 14-31.

Hook, J. L., \& Pettit, B. (2016). Reproducing occupational inequality: Motherhood and occupational segregation. Social Politics: International Studies in Gender, State \& Society, 23(3), 329-362.

Jacobs, J. \& Gerson, K. (2004). The time divide: Work, family, and gender inequality. Cambridge: Harvard University Press.

Jaumotte, F. (2003). Female labour force participation: Past trends and main determinants in OECD countries (OECD Economics Department Working Papers No. 376). Paris: OECD Publishing.

Kamerman, S. B., \& Kahn, A. J. (1994). Family policy and the under-3s: Money, services, and time in a policy package. International Social Security Review, 47(34), 31-43.

Keck, W., \& Saraceno, C. (2013). The impact of different social-policy frameworks on social inequalities among women in the European union: The labour-market participation of mothers. Social Politics, 20(3), 297-328.

Kil, T., Neels, K., Wood, J., \& de Valk, H. A. (2018). Employment after parenthood: Women of migrant origin and natives compared. European Journal of Population, 34(3), 413-440.

Kil, T., Wood, J., \& Neels, K. (2018). Parental leave uptake among migrant and native mothers: Can precarious employment trajectories account for the difference? Ethnicities, 18(1), 106-141.

Korpi, W., Ferrarini, T., \& Englund, S. (2013). Women's opportunities under different family policy constellations: Gender, class, and inequality tradeoffs in Western countries re-examined. Social Politics: International Studies in Gender, State \& Society, 20(1), 1-40.

Kremer, M. (2007). How welfare states care: Culture, gender and parenting in Europe. Amsterdam: Amsterdam University Press.

Lalive, R., \& Zweimüller, J. (2009). How does parental leave affect fertility and return to work? Evidence from two natural experiments. The Quarterly Journal of Economics, 124(3), 1363-1402.

Maldonado, L. C., \& Nieuwenhuis, R. (2015). Family policies and single parent poverty in 18 OECD countries, 1978-2008. Community, Work \& Family, 18(4), $395-415$. 
Mandel, H. (2011). Rethinking the paradox: Tradeoffs in work-family policy and patterns of gender inequality. Community, Work \& Family, 14(2), 159-176.

Mandel, H. (2012). Winners and losers: The consequences of welfare state policies for gender wage inequality. European Sociological Review, 28(2), 241-262.

Mandel, H., \& Semyonov, M. (2005). Family policies, wage structures, and gender gaps: Sources of earnings inequality in 20 countries. American Sociological Review, 70(6), 949-967.

Mandel, H., \& Semyonov, M. (2006). A welfare state paradox: State interventions and women's employment opportunities in 22 countries. American Journal of Sociology, 111(6), 1910-1949.

Mandel, H., \& Shalev, M. (2009). How welfare states shape the gender pay gap: A theoretical and comparative analysis. Social Forces, 87(4), 1873-1911.

McRae, S. (2003). Constraints and choices in mothers' employment careers: A consideration of Hakim's preference theory. The British Journal of Sociology, 54(3), 317-338.

Misra, J., Budig, M., \& Boeckmann, I. (2011). Work-family policies and the effects of children on women's employment hours and wages. Community, Work \& Family, 14(2), 139-157.

Misra, J., Budig, M. J., \& Moller, S. (2007). Reconciliation policies and the effects of motherhood on employment, earnings and poverty. Journal of Comparative Policy Analysis, 9(2), 135-155.

Müller, K. U., \& Wrohlich, K. (2018). Does subsidized care for toddlers increase maternal labor supply? Evidence from a large-scale expansion of early childcare (DIW Berlin Discussion Paper No. 1747).

Nieuwenhuis, R. (2014). Family policy outcomes: Combining institutional and demographic explanations of women's employment and earnings inequality in OECD countries, 1975-2005. Available at SSRN 2438617.

Nieuwenhuis, R., Need, A., \& Van Der Kolk, H. (2012). Institutional and demographic explanations of women's employment in 18 OECD countries, 1975-1999. Journal of Marriage and Family, 74(3), 614-630.

Nieuwenhuis, R., Need, A., \& Van der Kolk, H. (2017). Is there such a thing as too long childcare leave? International Journal of Sociology and Social Policy, 37(1/2), $2-15$.

Olivetti, C., \& Petrongolo, B. (2017). The economic consequences of family policies: Lessons from a century of legislation in high-income countries. Journal of Economic Perspectives, 31(1), 205-230.

Pavolini, E., \& Van Lancker, W. (2018). The Matthew effect in childcare use: A matter of policies or preferences? Journal of European Public Policy, 25(6), 878893.

Pettit, B., \& Hook, J. (2005). The structure of women's employment in comparative perspective. Social Forces, 84(2), 779-801.

Pettit, B., \& Hook, J. (2009). Gendered tradeoffs: Family, social policy, and economic inequality in twenty-one countries. New York: Russell Sage. 
Pfau-Effinger, B. (2005). Culture and welfare state policies: Reflections on a complex interrelation. Journal of Social Policy, 34(1), 3-20.

Pollmann-Schult, M. (2016). What mothers want: The impact of structural and cultural factors on mothers' preferred working hours in Western Europe. Advances in Life Course Research, 29, 16-25.

Ray, R., Gornick, J. C., \& Schmitt, J. (2010). Who cares? Assessing generosity and gender equality in parental leave policy designs in 21 countries. Journal of European Social Policy, 20(3), 196-216.

Rosenfeld, R. A., Van Buren, M. E., \& Kalleberg, A. L. (1998). Gender differences in supervisory authority: Variation among advanced industrialized democracies. Social Science Research, 27(1), 23-49.

Rubery, J., \& Figueiredo, H. (2018). Gender, employment and social policy. In S. Shaver (Ed.), Handbook on gender and social policy (pp. 129-152). Cheltenham: Edward Elgar.

Saraceno, C., \& Keck, W. (2008). The institutional framework of intergenerational family obligations in Europe: A conceptual and methodological overview (Multilinks project, WP1). Berlin: WZB Social Science Research Center.

Shalev, M. (2008). Class divisions among women. Politics \& Society, 36(3), 421444.

Sorensen, A. (1994). Women, family, and class. Annual Review of Sociology, 20: 27-47.

Steiber, N., \& Haas, B. (2009). Ideals or compromises? The attitude-behaviour relationship in mothers' employment. Socio-Economic Review, 7(4), 639-668.

Steiber, N., \& Haas, B. (2012). Advances in explaining women's employment patterns. Socio-Economic Review, 10(2), 343-367.

Steiber, N., Berghammer, C., \& Haas, B. (2016). Contextualizing the education effect on women's employment: A cross-national comparative analysis. Journal of Marriage and Family, 78(1), 246-261.

Svallfors, S. (2006). The moral economy of class: Class and attitudes in comparative perspective. Palo Alto, CA: Stanford University Press.

Thévenon, O. (2009). Increased women's labour force participation in Europe: Progress in the work-life balance or polarization of behaviours? Population, 64(2), 235-272.

Thévenon, O. (2016). Do 'institutional complementarities' foster female labour force participation? Journal of Institutional Economics, 12(2), 471-497.

Thévenon, O., \& Solaz, A. (2013). Labour market effects of parental leave policies in OECD countries (OECD Social, Employment and Migration Working Papers 141). OECD.

Uunk, W. (2015). Does the cultural context matter? The effect of a country's genderrole attitudes on female labor supply. European Societies, 17(2), 176-198.

Uunk, W., \& Lersch, P. M. (2019). The effect of regional gender-role attitudes on female labour supply: A longitudinal test using the BHPS, 1991-2007. European Sociological Review, 35(5), 669-683. 
Uunk, W., Kalmijn, M., \& Muffels, R. (2005). The impact of young children on women's labour supply: A reassessment of institutional effects in Europe. Acta Sociologica, 48(1), 41-62.

Van der Lippe, T., \& Van Dijk, L. (2002). Comparative research on women's employment. Annual Review of Sociology, 28(1), 221-241.

Van Lancker, W. (2013). Putting the child-centred investment strategy to the test: Evidence for the EU27. European Journal of Social Security, 15(1), 4-27.

Van Lancker, W. (2018). Does the use of reconciliation policies enable single mothers to work? A comparative examination of European countries. In R. Nieuwenhuis \& L. C. Maldonado (Eds.), The triple bind of single-parent families (pp. 239-261). Bristol, United Kingdom: Policy Press.

Vidal-Coso, E. (2019). Female employment following childbirth: Differences between native and immigrant women in Switzerland. Journal of Ethnic and Migration Studies, 45(9), 1667-1692.

Ziefle, A., \& Gangl, M. (2014). Do women respond to changes in family policy? A quasi-experimental study of the duration of mothers' employment interruptions in Germany. European Sociological Review, 30(5), 562-581.

Open Access This chapter is licensed under the terms of the Creative Commons Attribution 4.0 International License (http://creativecommons.org/licenses/by/4.0/), which permits use, sharing, adaptation, distribution and reproduction in any medium or format, as long as you give appropriate credit to the original author(s) and the source, provide a link to the Creative Commons licence and indicate if changes were made.

The images or other third party material in this chapter are included in the chapter's Creative Commons licence, unless indicated otherwise in a credit line to the material. If material is not included in the chapter's Creative Commons licence and your intended use is not permitted by statutory regulation or exceeds the permitted use, you will need to obtain permission directly from the copyright holder. 